\title{
Scanning Electron Microscopy of the Gastrointestinal Tract of Nile Perch (Lates niloticus, Linneaus, 1758)
}

\author{
Microscopía Electrónica de Barrido del Tracto Gastrointestinal \\ de la Perca del Nilo (Lates niloticus, Linnaeus, 1758)
}

Victoria Tibenda Namulawa*; Charcles Drago Kato**; Edward Nyatia**; Justus Rutaisire* \& Peter Britz ${ }^{* * *}$

\begin{abstract}
NAMULAWA, V. T.; KATO, C. D.; NYATIA, E.; RUTAISIRE, J. \& BRITZ, P. J. Scanning electron microscopy of the gastrointestinal tract of nile perch (Lates niloticus, Linneaus, 1758). Int. J. Morphol., 31(3):1068-1075, 2013.

SUMMARY: The morphology of the gastrointestinal tract of adult Nile perch was described using standard SEM procedures. Investigations revealed the presence of cardiform teeth in the oral cavity, goblet cells and finger print-like microridges on the hard palate and oesophagus lumenal surface. Elaborate patterns and bacterial cells were observed on the stomach lumenal surface and intense foldings in the intestinal region. These observations provide a better understanding of the morphology of the gut in Nile perch and how it is suited for its digestive function.
\end{abstract}

KEY WORDS; Gastrointestinal tract; Lates niloticus; Scanning electron microscopy.

\section{INTRODUCTION}

The digestive system is as important as food is to survival in animals. The anatomical characteristics of this system are dependent upon the food, habitat, and nutritional status of the organism (Delashoub et al., 2010). In fish, the morphology of the gastrointestinal tract explains how food is acquired, ingested, digested and assimilated (Cahu et al., 1998; Garcia-Hernandez et al., 2001; Chen et al., 2005; Ostaszewskaa et al., 2005). Gastrointestinal scanning electron microscopy (SEM) investigations have been widely used to provide a detailed anatomical description that betters the understanding of the operation of this system in fishes. Yashpal et al. (2006), have used this technique to investigate the surface architecture of the mouth cavity of Rita rita; Carrassón \& Matallanas (2006) used SEM to study the digestive tract in Dentex dentex; while Imtiyaz \& Ashok (2010) used the same technique to examine the intestinal tract of Schizothorax curifrons.

Nile perch (Lates niloticus) is a freshwater carnivorous fish occuring commonily the Lake Victoria basin and along the Nile River system. Limited information is documented about the morpholgy of its digestive system (Namulawa et al., 2011), which limits the understanding of how this system functions. The objective of this study was therefore to examine the surface architecture of the gastrointestinal tract of Nile perch so as to better the understanding of features of this tract in relation to its function.

\section{MATERIAL AND METHOD}

Sample collection. Two adult Nile perch samples weighing $3 \mathrm{~kg}$ and $5 \mathrm{~kg}$ were used in this study. The samples were collected from Lake Victoria in Uganda, in waters around Kiggungu fish landing site, located $32^{\circ} 26^{\prime} 15^{\prime \prime} \mathrm{E}, 00^{\circ} 2$ ' 49" N using long lines (hook No. 4 - 9).

Scanning Electron Microscopy (SEM). The oral cavity was accessed by examining the head. The head was excised with a sharp knife just behind the operculum and fixed in $10 \%$ formalin followed by $100 \%$ alcohol for three days before they were air drying. It was then split into two equal portions; one half was soaked in bleach (1\% Sodium hypochlorite) to soften the tissues attached to the bones. Teeth patches from the vomer, premaxilla, palatine, pterygoid, dentary, tongue, gill rakers and pharynx were teased out and air dried. These were then critical dried for 1.5 hours.

\footnotetext{
* Aquaculture Research \& Development Centre, 530, Kampala, Uganda.

** Collage of Veterinary Medicine, Animal Resources \& BioSecurity, Makerere University, 7062 Kampala, Uganda .

**** Department of Ichthyology \& Fisheries, Rhodes University 6140, Grahamstown, South Africa.
} 
The Gut section was accessed by dissecting live samples (sedated with clove oil) through an abdominal incision that revealed the digestive system. Small pieces $(2 \times 4 \mathrm{~mm})$ of gut sections (tongue, oesophagus, stomach, intestine, and liver) were fixed in $2.5 \%$ glutaraldehyde buffered in $0.1 \mathrm{M}$ phosphate in $2 \mathrm{ml}$ Eppendorfs. The soft gut pieces were dried in alcohol of increasing concentration $(30 \%, 50 \%, 70 \%, 80 \% 90 \%$, $100 \%$ ), and then critical point dried for 1.5 hours. The critical dried gut and teeth specimens were each mounted onto aluminium studs and gold sputtered in a Balzer Union sputtering Device model FL-9496 for 40 minutes. The gold sputtered specimens were then scanned using a Vega TESCAN Scanning Electron Microscope Model TC100, at a high voltage of $20.00 \mathrm{KV}$. Teeth measurements and counts were also done using the Scadium (Based on Analysis FIVE) software.

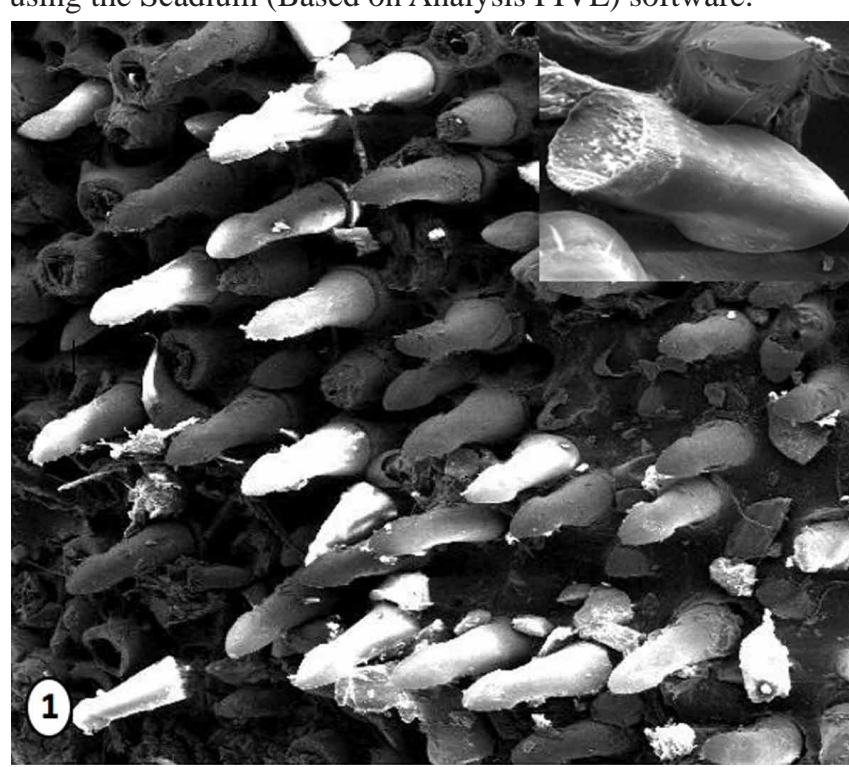

\section{RESULTS}

Oral cavity. Observations of the oral cavity made by the SEM showed that the teeth on all the oral plates (dentary, pharyngeal, palatine, vomer, and premaxilla), on the gill rakers and gill arches were cardiform, they had sharp monocuspid tips, wedge shaped- obliquely tunicate flattened crowns that bent towards the tip (Fig. 1). All teeth were directed towards the inside of the oral cavity and the pharynx; the teeth had hollow round bases that fit into round cups in the plates. Teeth counts indicated that the teeth length ranged between 120 and $400 \mathrm{~mm}$, while their density (number of teeth per square micro meter) ranged between 65 teeth and 400 teeth per square micro meter. The tongue surface was

Fig. 1. SEM micrographs of the teeth on the different plates in the oral cavity.

Fig. 2. SEM micrographs of the surface of the tongue. Notice the fungiform papilla covering the tongue surface.

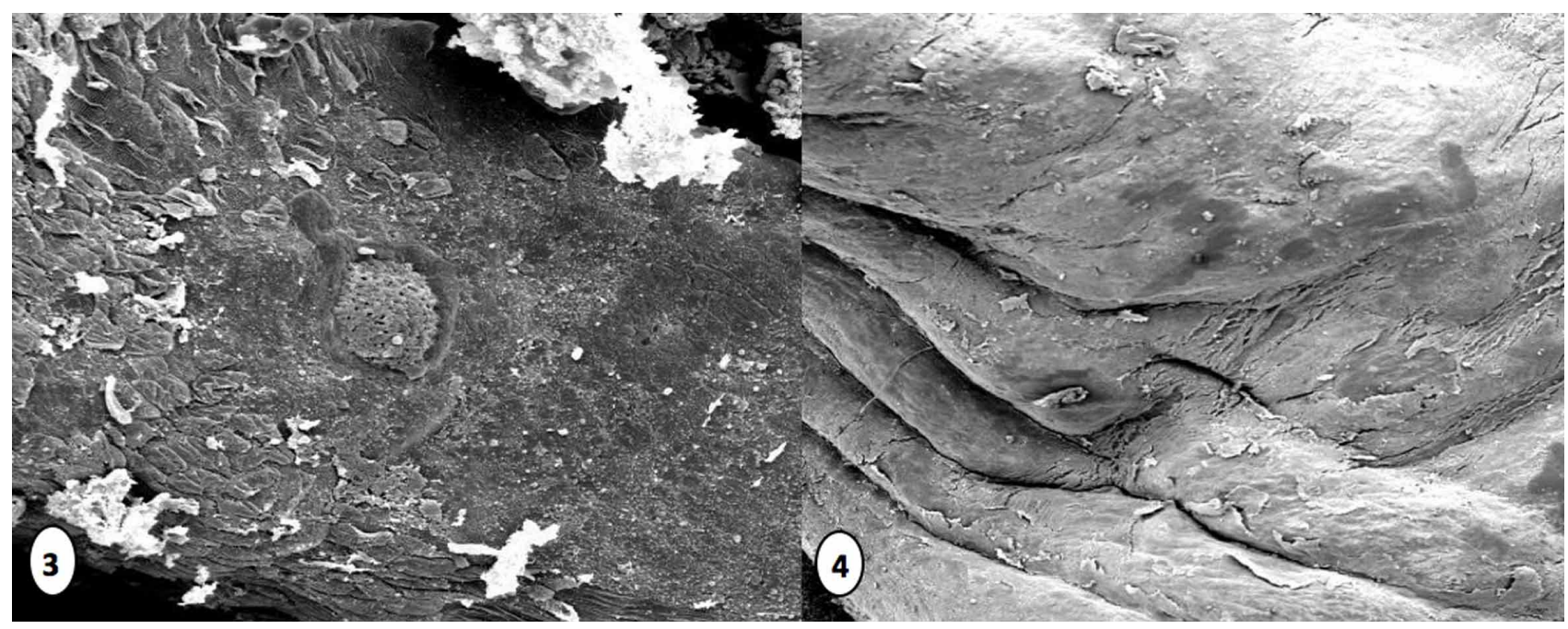

Fig. 3. SEM micrograph of the surface of the soft palate. Notice the goblet cell (GB) and the surface with finger print- like micro ridges (MR). Fig. 4. SEM micrographs of the surface of the hard palate. Notice the surface folds. 
covered with bacterial cells and papilla (Fig. 2). The surface of the soft palate was covered by a layer of mucus, goblet cells with a diameter of $28-50 \mathrm{~mm}$, surface cells with fingerprint-like micro ridges and bacterial cells (Fig. 3); while the hard palate surface was folded (Fig. 4).

Oesophagus. The oesophagus surface was irregular with finger print-like micro-ridges. It was also covered with a layer of mucus and bacterial cells (Fig. 5).
Stomach. Different patterns of folds were observed on the stomach lumenal surface in the different stomach regions. The surface in the cardiac region had a zigzag appearance with troughs and crests and gastric pit openings with a diameter of $8 \mathrm{~mm}-12 \mathrm{~mm}$ (Fig. 6). The stomach surface in the fundic region had the apical epithelial cells arranged in a mat-like pattern (Fig. 7). Sections of the lumenal surface of the fundic region appeared with polygon-shaped cells with a diameter of 23-37 mm (Fig. 8). The epithelium at the blind

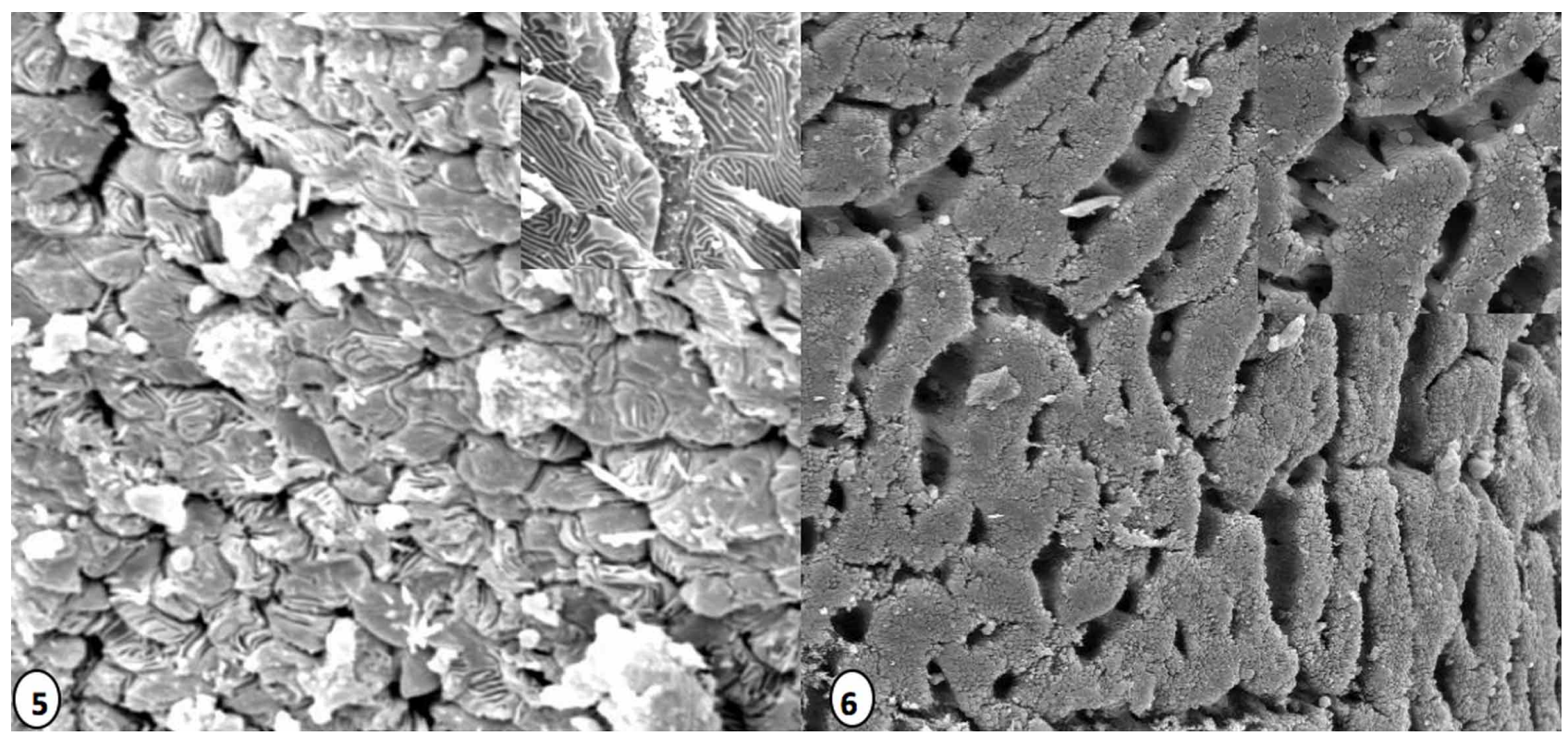

Fig. 5. SEM micrographs of the oesophagus lumen surface. Notice the mucus patches (MP) on the surface and the polygon-shaped surface cells (SC) with finger print-like micro ridges (MR).

Fig. 6. SEM micrograph of the lumenal surface in the cardiac region of the stomach. Notice the gastric pit openings occurring between surface apical cells and the zigzag pattern.

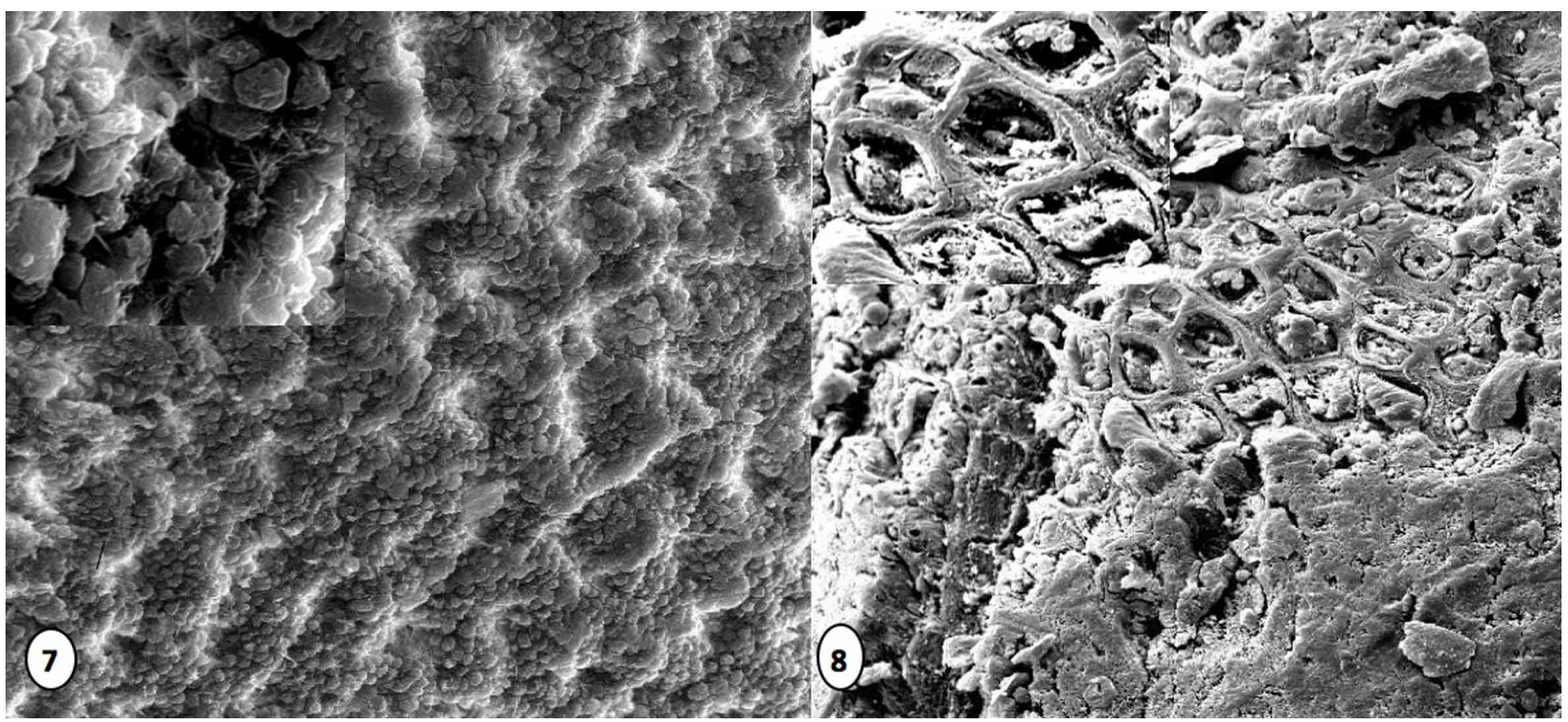

Fig. 7. SEM micrographs of the lumenal surface of the fundic region of the stomach. Notice the undulating pattern.

Fig. 8. SEM micrographs of the lumenal surface of the fundic region of the stomach. Notice the honey comb-shaped pattern. 
end was covered by a layer of mucus and gastric pits (Fig. 9). Bacterial cells commonly occurred in all the stomach regions while the pylorus surface (Fig. 10) and pyloric sphincter region were covered by mucous and greatly folded (Fig. 11).

Pyloric ceaca and intestine. The ceaca (Fig. 12), anterior
(Fig. 13), middle (Fig. 14) and hind intestine (Fig. 15) lumenal surfaces were greatly folded and covered with mucus. The surface folds in the different sections also had different patterns. The folds in the caeca, anterior and middle intestine were more elaborate compared to those observed in the hind intestine.

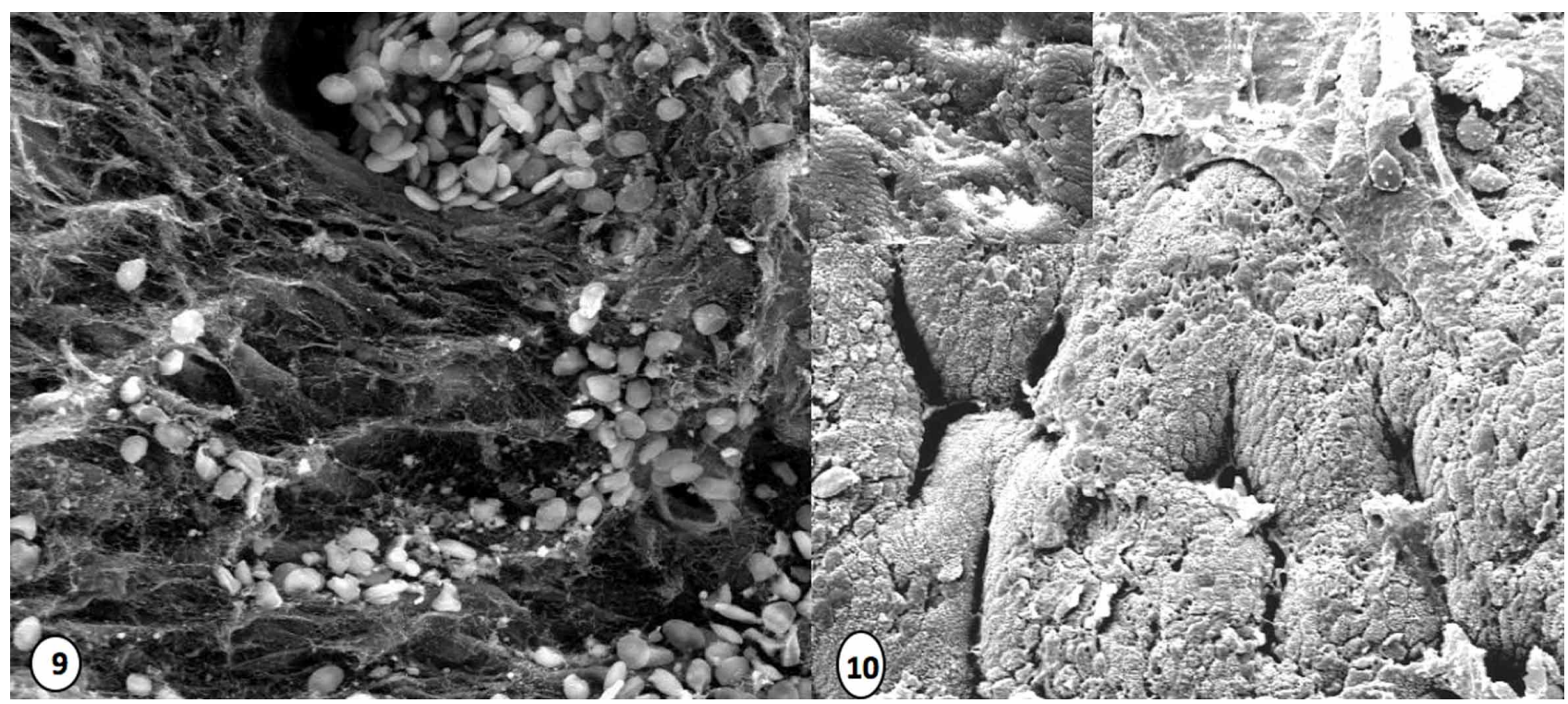

Fig. 9. SEM micrograph of the lumenal surface of the blind end region of the stomach. Notice the mucous covering the surface and the gastric pit openings.

Fig. 10. SEM micrographs of the lumenal surface of the pylorus region of the stomach. Notice the mucus covering the surface cells.

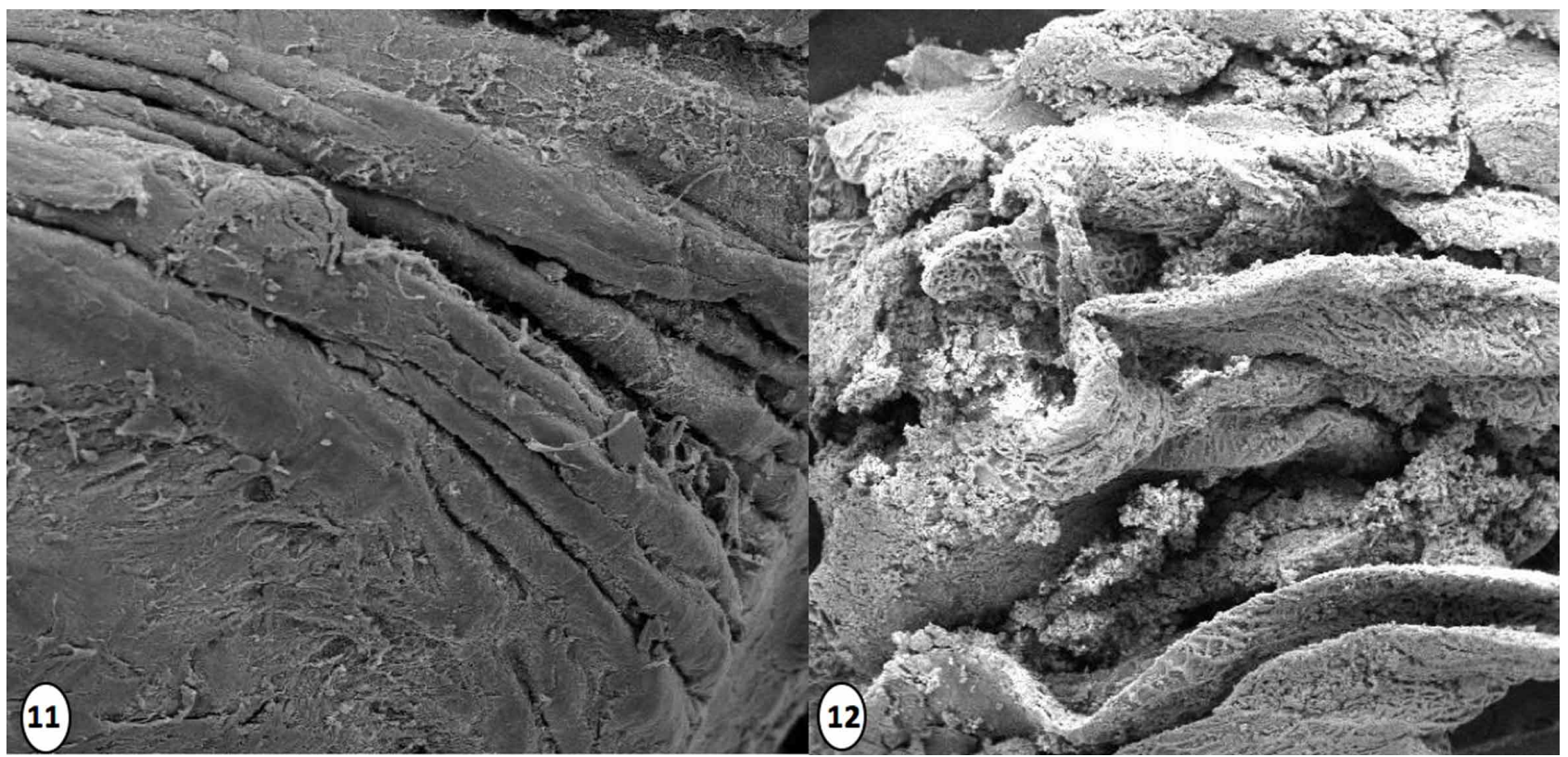

Fig. 11. SEM micrographs of the lumenal of the pyloric sphincter region of the stomach. Notice the muscle folding.

Fig. 12. SEM micrographs of the lumenal surface of the caeca. Notice the folding of the lumen surface. 


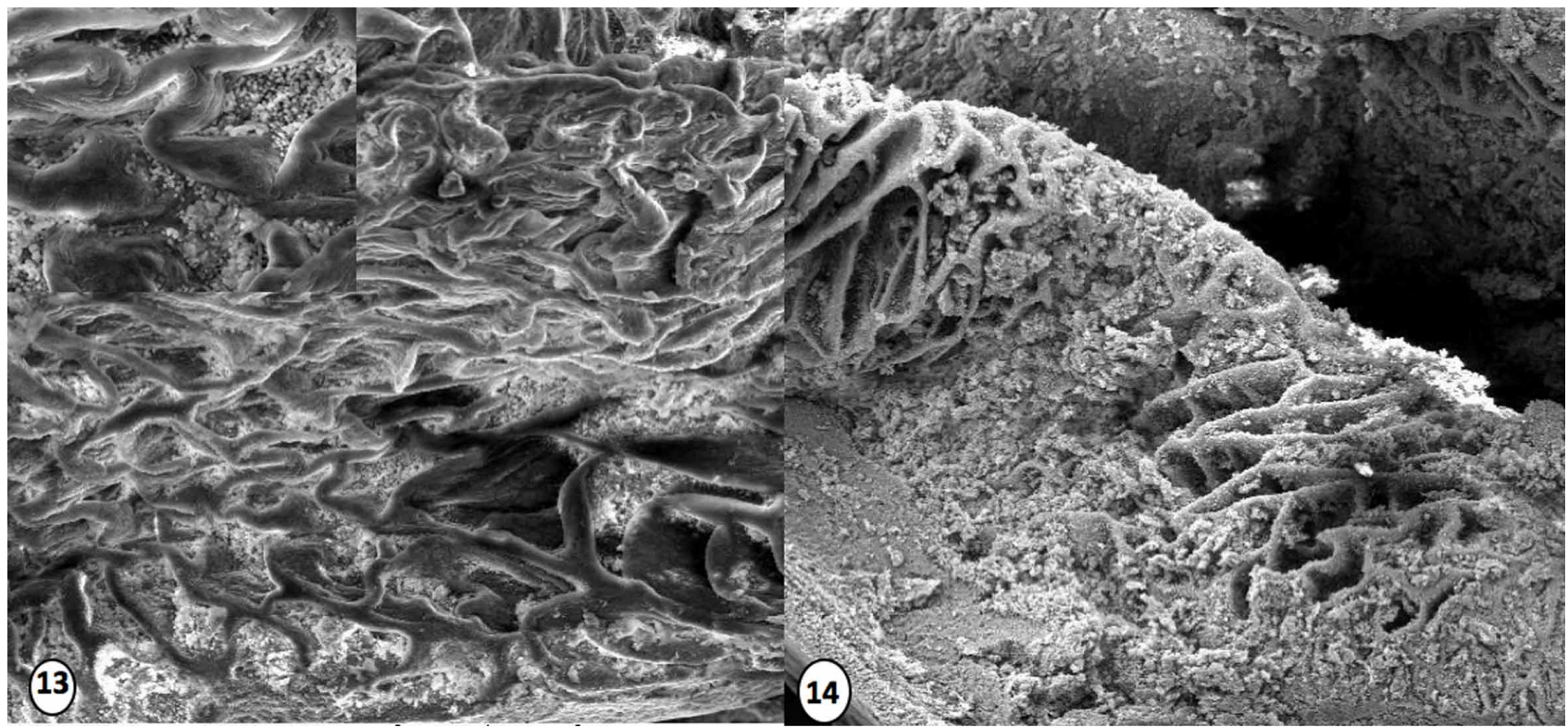

Fig. 13. SEM micrographs of the lumenal surface of the anterior intestine. Notice the folding of the lumen surface.

Fig. 14. SEM micrographs of the lumenal surface of the middle intestine. Notice the folding of the lumen surface.

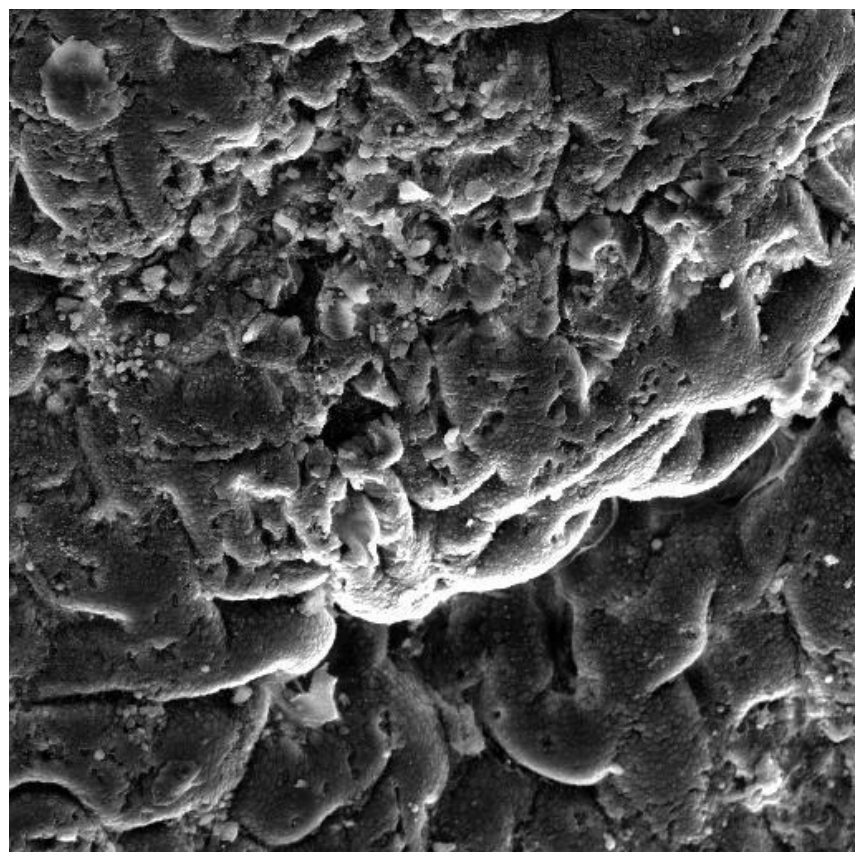

Fig. 15. SEM micrographs of the lumenal surface of the hind intestine. Notice that the lumen surface is greatly folded.

\section{DISCUSSION}

SEM investigations of the oral cavity in Nile perch indicate the presence of a uniform cardiform detention on the oral plates, confirming that Nile perch is an obligate piscivore. The cardiform, monocuspid sharp crowned teeth observed in
Nile perch may explain how live prey is captured, effectively held and pushed down the oesophagus without breaking into pieces. Similar dentition indicating piscivory have been observed in other predatory fish, such as Barramundi with villiform teeth (Russell, 1987); pike perch with cardiform and canine teeth (Specziár \& Bíró, 2003), and in the largemouth bass with villiform teeth (Tamilselvi, 2010).

Swallowing in this fish is probably eased by the presence of the mucus in the buccal cavity which was observed by SEM. The mucus serves to reduce friction in the path of entry of the prey making swallowing possible. The fingerprint-like micro ridges observed on the surface cells in the oral cavity and oesophagus in Nile perch are similar to those reported in Solea senegalensis (Arellano et al., 2001), in Dentex dentex (Carrassón \& Matallanas), in Seriola dumerilli (Grau et al., 1992), in Rita rita (Yashpal et al.), and in several other seawater and freshwater fishes (Meister et al., 1983). These ridges have been thought to play an important role of protecting the buccal-oesphageal surface from trauma and providing an anchor to the mucus secreted from the goblet cells (Wilson \& Castro, 2010). This observation suits the function of micro ridges observed in the Nile perch, since it ingests live prey that could inflict trauma to the oral cavity and oesophageal regions on ingestion.

The stomach surface in Nile perch has an irregular luminal surface, manifesting varying complicated patterns. This observation has been cited in Onchorynchusmykiss 
(Ezeasor \& Stokoe, 1980), in Mystus aor (Sinha \& Chakrabarti, 1986), and in Rhamdia quelen (Hernández et al., 2009). These complex foldings probably provide for the extension of the stomach capacity during ingestion and increase the surface area during digestion.

Bacterial cells were observed in the oral cavity, oesophagus and in the stomach of Nile perch. Similar bacteria may occur in the intestine; however, the techniques used in this study were not efficient to identify them in that region. Gut flora has been reported in lower organisms such as abalone (Erasmus et al., 1997), and in several higher vertebrates such as humans (Eckburg et al., 2005), cattle (Maki \& Picard, 1965), mice (Rawls et al., 2006), frogs (Pryor, 2008), and other fish (Sugita et al., 1989; Bairagi et al., 2002; Voveriene et al., 2002; Ringo et al., 2003; Korneva, 2008). Observations by Bairagi et al., indicate gut micro bacteria as an important source of amylase, cellulose, lipase and protease, while Voveriene et al., has recorded their role in hydrocarbon degradation in the fish gut. The presence of bacteria in the Nile perch gut may suggest their role in chemical digestion and defence as observed in the other fish, making the Nile perch gut more efficient, however, more investigations need to be performed to prove this possibility.

The pyloric sphincter in Nile perch is characterized by several muscular foldings. This sphincter occurs in several vertebrates (Smith et al., 2000) and in many fish species (Buddington \& Christofferson, 1985; Bergman et al., 2003). Some authors (Cai \& Gabella, 1984; Sundh 2009) have indicated that this sphincter remains closed until all the chemical digestion is completed in the stomach before the digesta moves on, thereby controlling the release of food into the intestine. This phenomenon may be possible in the Nile perch given the fact that the material observed to leave the stomach through the pyloric sphincter to the caeca is finely broken down, indicating that the sphincter is a means of ensuring effective chemical digestion before absorption proceeds in the intestine.

The lumenal of the caeca and intestine are greatly folded. Similar observations have been reported by Imtiyaz \& Ashok in the intestine of Schizothorax curviforns; these numerous folds suggest a means of increasing the surface area of assimilation in this region.

\section{CONCLUSION}

The morphology of the digestive system of Nile perch is characterized by several teeth cardiform teeth that are efficient for prey capture, a mucous layer that eases food movement, bacterial cells and an extensively folded stomach and intestinal luminal surfaces which aid digestion and assimilation. These findings provide a better understanding of the structure and functioning of the digestive system in this fish.

\section{ACKNOWLEDGEMENTS}

The authors appreciate the financial support from the World Bank, through the Uganda National Council of Science and Technology.

NAMUlAWA, V. T.; KATO, C. D.; NYATIA, E.; RUTAISIRE, J. \& BRITZ, P. J. Microscopía electrónica de barrido del tracto gastrointestinal de la perca del Nilo (Lates niloticus, Linnaeus, 1758). Int. J. Morphol., 31(3):1068-1075, 2013.

RESUMEN: El objetivo fue describir la morfología del tracto gastrointestinal de la perca del Nilo adulta mediante microscopía electrónica de barrido estándar. La investigación reveló la presencia de dientes cardiformes en la cavidad oral, células caliciformes y microcrestas como huellas digitales en el paladar duro y la superficie luminal del esófago. Se observaron patrones elaborados, así como bacterias en la superficie luminal del estómago, y plegamientos marcados en la región intestinal. Estas observaciones proporcionan una mejor comprensión de la morfología del intestino de la perca del Nilo y como se adapta para su función digestiva.

PALABRAS CLAVE: Tracto gastrointestinal; Lates niloticus; Microscopía electrónica de barrido.

\section{REFERENCES}

Arellano, J. M.; Storch, V. \& Sarasquete, C. A histological and histochemical study of the oesophagus and oesogaster of the Senegal sole, Solea senegalensis. Eur. J. Histochem., 45(3) :279-94, 2001.
Bairagi, A.; Ghosh, K.; Sen, S. \& Ray, A. Enzyme producing bacterial flora isolated from fish digestive tracts.Aquac. Int., 10:109-21, 2002. 
Bergman, A. N.; Laurent, P.; Otiang'a-Owiti, G.; Bergman, H. L.; Walsh, P. J.; Wilson, P. \& Wood, C. M. Physiological adaptations of the gut in the Lake Magadi tilapia, Alcolapia grahmi, an alkaline - and saline - adapted teleost fish. Comp. Biochem. Physio. A Mol. Integr. Physiol., 136(3):701-15, 2003

Buddington, R. \& Christofferson, J. Digestive and feeding characteristics of Chondrosteans. Environ. Biol. Fish., 14(1):31-41, 1985.

Cahu, C.; Zambonino Infante, J.; Escaffre, A M.; Bergot, P. \& Kaushik, S. Preliminary results on sea bass (Dicentrarchus labrax) larvae rearing with compound diets from first feeding. Comparison with carp (Cyprinus carpio) larvae. Aquaculture, 163(1-2):17, 1998.

Cai, W. Q. \& Gabella, C. Structure and innervation of the musculature at the gastroduodenal junction of the guinea pig. J. Anat., 139(Pt. 1):93-104, 1984.

Carrassón, M. \& Matallanas, J. Morphometric charateristics of the alimentary tract of deep - sea Mediterranean teleosts in relation to feeding habits. Mar. Biol., 118:319-22, 1994.

Chen, B. N.; Qin, J. G.; Kunar, M. S.; Hutchinson, W. \& Clarke, S. Ontogenetic development of the digestive system in yellowtail kingfish Seriola lalandi larvae. Aquaculture, 256(1-4):489-501, 2005.

Delashoub, M.; Pousty, I. \& Khojasteh, S. M. Histology of Bighead carp (Hypophthalmichthys nobilis) intestine. Global Vet., 5(6):302-6, 2010.

Eckburg, P. B.; Bik, E. M.; Bernstein, C. N.; Purdom, E.; Dethlefsen, L.; Sargent, M.; Gill, S. R.; Nelson, K. E. \& Relman, D. A. Diversity of the human intestinal microbial flora. Science, 308(5728):1635-8, 2005.

Erasmus, J. H.; Cook, P. A. \& Coyne, V. E. The role of bacteria in the digestion of seaweed by the abalone Haliotis midae. Aquaculture, 155(1-4):377-86, 1997.

Ezeasor, D. N. \& Stokoe, W. M. Scanning electon microscopic study of the gut mucosa of the rainbow trout Salmo gairdneri Richardson. J. Fish Biol., 17(5):529-39, 1980.

García-Hernández, M. P.; Lozano, M. T.; Elbal, M. T. \& Agulleiro, B. Development of the digestive tract of sea bass (Dicentrarchus labrax L). Light and electron microscope studies. Anat. Embryol., 204(1):39-57, 2001.

Grau, A.; Crespo, S.; Sarasquete, M. C. \& Gonzalez de Canales, M. L. The digestive tract of the amberjack Seriola dumerilli, Risso: a light and scaning electron microscope study. J. Fish Biol., 41(2):287-303, 1992.

Hernández, D. R; Gineselli, P. M. \& Domitovic, H. A. Morphology, histology and histochemistry of the digestive system of South American catfish (Rhamdia quelen). Int. J. Morphol., 27(1):105-11, 2009.
Imtiyaz, H. M. \& Ashok, C. Histochemical Distribution of Lipase and Acid Phosphatase in the Intestinal Tract of the Snow Trout, Schizothorax curvifrons Heckel. J. Biol. Sci., 10(7):643-7, 2010.

Korneva, J. V. Nanobacteria associated with mucous intestines of freshwater fishes and tegument of their parasites (Cestoda). Acta Parasit., 53(3):312-4, 2008.

Maki, L.R. \& Picard, K. Normal intestinal flora of cattle fed highroughage ratios. J. Bacteriol., 89:1244-9,1965.

Meister, M. F.; Humbert, W.; Kirsch, R. \& Vivien-Roels, B. Structure and ultrastructure of the oesophagus in sea-water and fresh-water teleosts. Zoomorphology, 102:33-51, 1983.

Namulawa, V. T.; Kato, C. D.; Nyatia, E.; Britz, P. \& Rutaisire. J. Histomorphological description of the digestive system of Nile perch (L. niloticus). Int. J. Morphol., 29(3):723-32, 2011.

Ostaszewskaa, T.; Dabrowskib, K.; Palaciosb, M. E.; Olejniczaka, M. \& Wieczoreka, M. Growth and morphological changes in the digestive tract of rainbow trout (Oncorhynchus mykiss) and pacu (Piaractus mesopotamicus) due to casein replacement with soybean proteins. Aquaculture, 245(1-4):273-86, 2005.

Pryor, G. S. Anaerobic bacteria isolated from the gastrointestinal tracts of Bullfrog tadpoles (Rana catesbeiana). Herpetol. Conserv. Biol., 3(2):176-81, 2008.

Rawls, J. F.; Mahowald, M. A.; Ley, R. E. \& Gordon, J. I. Reciprocal gut microbiota transplants from Zebrafish and mice germ-free recipients reveal host habitat selection. Cell, 127(2):423-33, 2006.

Ringo, E.; Olsen, R. E.; Mayhew, T. M. \& Myklebust, R. Electron microscopy of the intestinal microflora of fish. Aquaculture, 227(1-4):349-415, 2003.

Russell, D. J. Review of juvenile barramundi (Lates calcarifer) wildstocks in Australia. In: Copland, J. W. \& Grey, D. L. Management of wild and cultured seabass/barramundi (Lates calicarifer). Darwin, Australia, Proceedings of an International Workshop, Australian Center for International Agricultural Research, Proceedings Number 20, 1987. pp.44-9.

Sinha, G. M. \& Chakrabarti, P. Scanning electron microscopic studies on the mucosa of the digestive tract in Mystus aor (Hamilton). Proc. Indian Natn. Sci. Acad., B52(2):267-73, 2006.

Smith, D. M.; Grasty, R. C.; Theodosius, N. A.; Tabin, C. J. \& Nascone-Yoder, N. M. Evolutionary relationship between the amphibian, avian and mammalian stomachs. Evol. Devel., 2(6):348-59, 2000.

Specziár, A. \& Bíró, P. Population structure and feeding characteristics of Volga pike perch, Sander volgensis (Pisces, Percidae) in Lake Balaton. Hydrobiol., 506-509:503-10, 2003. 
NAMULAWA, V. T.; KATO, C. D.; NYATIA, E.; RUTAISIRE, J. \& BRITZ, P. J. Scanning electron microscopy of the gastrointestinal tract of nile perch (Lates niloticus, Linneaus, 1758). Int. J. Morphol., 31(3):1068-1075, 2013.

Sugita, H.; Iwata, J.; Miyajima, C.; Kubo, T.; Noguchi, T. \& Hashimoto, K. Changes in microflora of a puffer fish Fugu niphobles, with different water temperatures. Mar. Biol., 101:299-304, 1989.

Sundh, H. Chronic stress and intestinal barrier function: Implications for infection and inflammation in intensive salmon aquaculture. Department of Zoology, University of Gothenburg, Sweden, 2009.

Tamilselvi, S. Environment-induced phenotypic plasticity in the teeth of hatchery and wild Largemouth bass, Micropterus floridanus. Masters thesis and specialist projects, Western Kentucky University, 2010.

Voveriene, G.; Mickeniene, L. \& Syvokiene, J. Hydrocarbondegrading bacteria in the digestive tract of fish, their abundance, species composition and activity. Acta Zool. Litu, 12(3):33340, 2002.

Wilson, J. M. \& Castro, L. F. Morphological Diversity of the Gastrointestinal Tract in Fishes. In: Martin, G.; Farrel, A. P. \& Brauner, C. J. (Eds.). The Multifuctional Gut of Fish. London, Academic Press, 2010. pp.2-44.

Yashpal, M.; Kumari, U.; Mittal, S. \& Mittal. A. K. Surface architecture of the mouth cavity of a canivorous fish Rita rita (Hamilton, 1822) (Siluriforms, Bagridae). Belg. J. Zool., 136(2):155-62, 2006.
Correspondence to:

Victoria Tibenda Namulawa

Aquaculture Research \& Development Centre

530, Kampala

UGANDA

Email: tibendavyky@yahoo.com

Received: 06-02-2013

Accepted: 12-08-2013 